\title{
Effect of environmental parameters on squamate reptiles in an urban forest fragment in central Amazonia
}

\author{
Thais ALMEIDA-CORRÊA ${ }^{1}$, Luciana FRAZÃO², Diogo Magalhães COSTA³, \\ Marcelo MENIN $^{3}$, Igor Luis KAEFER ${ }^{3 *}$ (]) \\ Instituto Nacional de Pesquisas da Amazônia, Programa de Pós-Graduação em Ecologia, Av. André Araújo 2936, 69060-001, Manaus, AM, Brazil \\ Universidade do Estado do Amazonas, Programa de Pós-Graduação em Biodiversidade e Biotecnologia da Amazônia Legal - BIONORTE, Av. Carvalho Leal 177, \\ Prédio Anexo $4^{\circ}$ andar, 69065-001, Manaus, AM, Brazi \\ 3 Universidade Federal do Amazonas, Instituto de Ciências Biológicas, Av. General Rodrigo Otávio Jordão Ramos 6200, 69077-000, Manaus, AM, Brazil \\ * Corresponding author: kaefer@ufam.edu.br; (D) https://orcid.org/0000-0001-6515-0278
}

\begin{abstract}
The increasing urbanization of the Amazonian biome has promoted the creation of several forest fragments surrounded by an urban matrix, but the relationship of animal assemblages to the urban environment, especially in forest fragments, is poorly known. Here we aimed to 1) determine the composition of the squamate fauna of the largest urban forest fragment from central Amazonia, in the Brazilian city of Manaus, and 2) evaluate the influence of environmental parameters on assemblage diversity. We sampled 10 standardized riparian plots through visual search in six surveys between 2008/09 and 2015, totaling 360 observer-hours. We found 15 species of lacertoids (lizards and amphisbaenians) and seven species of snakes through active search. After considering occasional encounters and search in museum collections, we recorded a total of 24 lacertoid and 22 snake species. Multiple regression models indicated that species richness and abundance of individuals increased with the distance from the edge of the fragment, while other structural parameters of the environment did not affect the assemblage. We conclude that this forest fragment 1) consists of a subset of the regional species pool, and 2) undergoes reduction of species richness and abundance of individuals from the center to the borders. This and additional urban forest fragments should be continually monitored in order to evaluate their long-term role in maintaining the tropical biodiversity.
\end{abstract}

KEYWORDS: amphisbaenians, edge effect, lizards, snakes, urban ecology

\section{Efeito de parâmetros ambientais sobre répteis escamados em um fragmento florestal urbano na Amazônia Central}

\section{RESUMO}

A crescente urbanização do bioma amazônico promoveu a criação de vários fragmentos florestais cercados por uma matriz urbana, mas a relação das assembleias de animais com o ambiente urbano, especialmente nos fragmentos florestais, é pouco conhecida. Aqui, objetivamos 1) determinar a composiçáo da fauna de répteis escamados do maior fragmento de floresta urbano da Amazônia Central, na cidade brasileira de Manaus, e 2) avaliar a influência de parâmetros ambientais sobre a diversidade desta assembleia. Foram amostradas 10 parcelas ripárias padronizadas por meio de busca visual em seis amostragens entre 2008/09 e 2015, totalizando 360 horas-observador. Encontramos 15 espécies de lacertóideos (lagartos e anfisbenas) e sete espécies de serpentes por meio de busca ativa. Após considerar encontros ocasionais e coleçóes científicas, registramos um total de 24 espécies de lacertóideos e 22 espécies de serpentes. Modelos de regressão múltipla indicaram que a riqueza de espécies e abundância de indivíduos aumentaram com a distância da borda do fragmento, enquanto outras variáveis estruturais do ambiente não afetaram a assembleia. Concluímos que este fragmento florestal 1) consiste em um subamostra do conjunto regional de espécies, e 2) sofre redução da riqueza de espécies e abundância de indivíduos do centro para as bordas. Este e outros fragmentos de floresta urbana deveriam ser monitorados continuamente para avaliar seus papéis a longo prazo na manutenção da biodiversidade tropical.

PALAVRAS-CHAVE: anfisbenas, efeito de borda, lagartos, serpentes, ecologia urbana 


\section{INTRODUCTION}

In areas under constant anthropogenic pressure, specific changes in habitat components might affect the composition and distribution of squamate reptiles (Gardner et al. 2007; Folt and Reider 2013). Changes such as increases in temperature and decreases in humidity, may affect microhabitats and suitable reproductive sites or impact the dispersal ability for Squamata, causing local extirpation of this group, mainly in smaller forest patches (Laurance 2002; Araújo and Pearson 2005; Gardner et al. 2007). The increasing urbanization of the Amazonian biome has promoted the creation of several forest fragments surrounded by an urban matrix (Grimm et al. 2000; Chace and Walsh 2006). Understanding the relationship between reptiles and this environment can create subsidies for urban planning that maximizes the conservation of this diverse fauna (Grimm et al. 2000; Chace and Walsh 2006). Knowledge about the composition and ecology of squamate reptile assemblages in central Amazonia mainly comes from studies in peri-urban/rural or continuous forest areas (e.g. Martins and Oliveira 1998; Neckel-Oliveira and Gordo 2004; Fraga et al. 2013a). Therefore, the relationship of these assemblages with the urban environment, especially in forest fragments, is poorly known.

Diversity of forest-dwelling Amazonian squamates can be affected by stream and leaf-litter characteristics that compose the physical structure of the environment occupied by squamates and affect niche dimensions such as thermal conditions and refuge and prey availability (e.g. Pinto 2006; Faria et al. 2019; Masseli et al. 2019). In Amazonian forest patches, the distance from the edge of the fragment is also known to affect the composition of biological communities such as plants, mammals, birds and amphibians, because a myriad of correlated environmental variables (e.g. humidity, temperature, luminosity) change directionally from the edge to the center of the fragment (Zimmerman and Rodrigues 1990; Lewis et al. 2009; Rojas and Pérez-Peña 2018). Many species of squamate reptiles have specific microhabitat requirements (Ávila-Pires et al. 1995; Peixoto et al. 2020). Therefore, the analysis of the edge effect on Amazonian squamates may allow to test how urbanization-induced fragmentation affects these animals and produce subsidies for the adoption of taxonoriented conservation strategies.

The city of Manaus is the largest metropolis in the central Brazilian Amazon. It undergoes intense urban growth and reduction/fragmentation of forest cover. From 314,197 inhabitants in 1970 (IBGE 1970), Manaus currently has a population of more than 1.8 million inhabitants (IBGE 2018). Consequently, the region of Manaus has been transformed into a mosaic of landscapes that could be an interesting model for studies in urban ecology. We aimed to determine the composition of the squamate fauna of an urban forest fragment in Manaus. Specifically, we aimed to evaluate the influence of environmental parameters on assemblage diversity. We tested the general hypothesis that the squamate reptile assemblage is affected by the edge distance, and not by other structural characteristics of the environment (stream size and leaf litter depth), given that edge distance may act as a proxy for a series of additional (mostly climatic) environmental parameters that change from the borders to the core of the forest fragment (Laurance and Vasconcelos 2009). We predicted that the distance from the edge will exert an impact on species richness and abundance of individuals.

\section{MATERIAL AND METHODS}

\section{Study site}

This study was conducted in one of the largest urban forest fragments of the planet: the 776-ha campus of Universidade Federal do Amazonas (UFAM) (Marcon et al. 2012) (0304'34"S, 5957'30"W; DATUM = WGS84) located in the city of Manaus, in the Brazilian state of Amazonas (Figure 1). This area has a tropical rainforest physiognomy and consists in a mosaic of different vegetation structures, mainly composed of primary and secondary forest, as well as anthropic areas (Nery et al. 2004; Marcon et al. 2012). The region has a tropical monsoon climate, with an annual average temperature of $26^{\circ} \mathrm{C}$ and total precipitation of $2362 \mathrm{~mm}$ (Alvares et al. 2013). Most of the precipitation is concentrated in a rainy season that extends from November to May (Alvares et al. 2013).

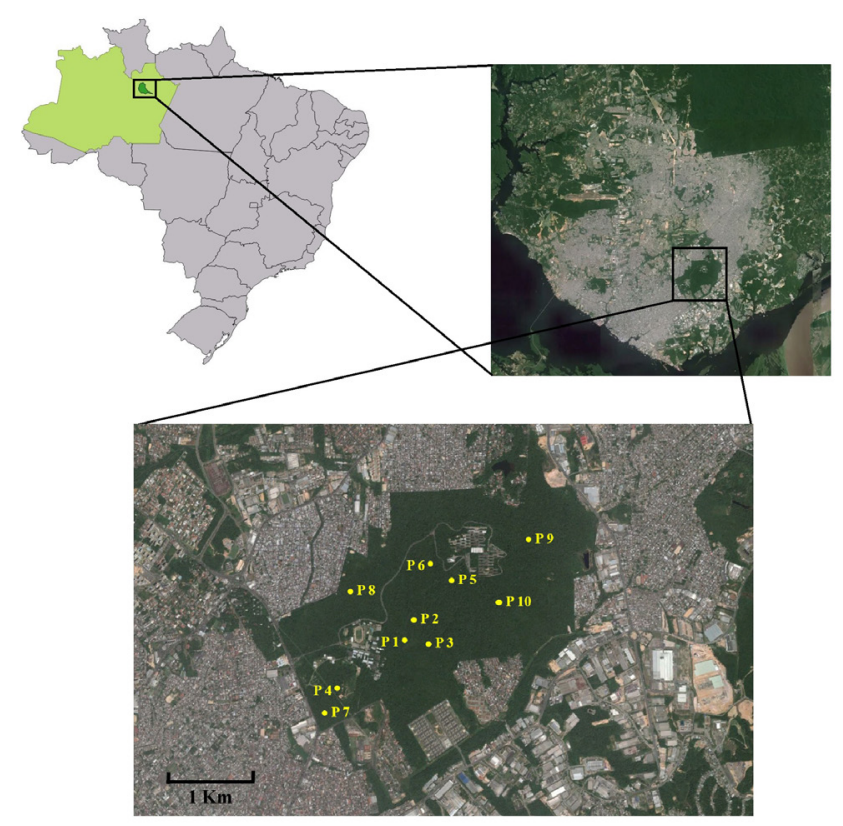

Figure 1. Urban forest fragment of the campus of Universidade Federal do Amazonas, in the Brazilian city of Manaus, and location of 10 sampling plots (P1 to $\mathrm{P} 10)$. This figure is in color in the electronic version. 
Data collection. We used 10 riparian plots in a sampling grid installed in the campus following the RAPELD protocol (Magnusson et al. 2005), implemented in 2008 by TsujiNishikido and Menin (2011). Each plot is a standardized sampling unit $250 \mathrm{~m}$ long and $10 \mathrm{~m}$ wide, following the altitudinal contour in order to avoid variation in habitat characteristics. We conducted six surveys (three diurnal and three nocturnal) of two hours in each plot (Fraga et al. 2011). The first three surveys were conducted from April 2008 to January 2009, and the three remaining surveys from January to July 2015. Observers were not the same on each survey, but all observers were equally trained by the same team of leading researchers. Even though we cannot discard that detectability varied due to observer bias, we assume that this variation was minimal across samplings.

Both sampling periods (2008-2009 and 2015) comprised surveys both in dry and rainy season. We used Time Constrained Search (TCS) associated with raking through leaf litter, which was conducted by searching horizontally (up to five meters on each side) and vertically (up to five meters high) along the plot (Crump and Scott 1994; Martins and Oliveira 1998). In order to search for fossorial species, we moved the litter and fallen logs. We conducted TCS following the sequence of space-makers along the plots from 0 to 250 $\mathrm{m}$, for one hour. In the reverse direction, we used raking through leaf litter along the plot, also for one hour. During each sampling, we surveyed each plot for two hours, with three observers, resulting in a total sampling effort of 360 observer-hours. Species were identified based on identification guides and specialized literature (Vitt et al. 2008; Fraga et al. 2013b; Costa and Bérnils 2018). Herpetological collections of UFAM and Instituto Nacional de Pesquisas da Amazônia (INPA) were consulted in order to search for additional species records from the studied forest fragment. Occasional sightings outside the sampling grid and data from museum collections were used only to compose the list of species occurrence in the fragment area and were not considered in ecological analyses.

\section{Environmental parameters}

All environmental parameters were measured for the first sampling period [see details in Tsuji-Nishikido and Menin (2011)]: 1) Stream size, determined by the product of width and depth of the stream, with the length of the plot $(250 \mathrm{~m})$; 2) Edge distance, determined by the distance of the plot to the nearest edge of the forest fragment; 3) Average litter depth, recorded with a graduated stick $(\mathrm{cm})$ on six equally-distant points along the plot. Average valley width was measured but was not considered in the analyses because it was collinear with edge distance (Tsuji-Nishikido and Menin 2011).

\section{Data analyses}

Squamate abundance and richness from both sampling periods, as well as the environmental variables, were submitted to the Shapiro-Wilk normality test. The effect of the environmental parameters (stream size, edge distance, litter depth) on abundance of individuals and species richness of squamate reptiles was tested with a multiple linear regression model (Species richness or abundance $=\alpha+$ stream size + edge distance + litter depth). Considering the typical low vagility of squamate reptiles (Vitt et al. 2008; Fraga et al. 2013b) and the lack of correlation between the geographical distances among plots and most of the environmental parameters (TsujiNishikido and Menin 2011), we considered the sampling units to be independent. All analyses were performed in the R computational environment (R Core Team 2019).

\section{RESULTS}

\section{Species composition}

We recorded a total of 209 individuals from 15 lizard species and 23 individuals from seven snake species in the plots (Table 1). One lizard species and four snake species were listed only as occasional encounters. Also, five lacertoid species and two snake species were only found in the museum search. The most speciose genera were Amphisbaena and Norops with

Table 1. Number of individuals of squamate reptiles found in the campus of Universidade Federal do Amazonas (UFAM), Manaus, Brazil. Coll = zoological collection. ${ }^{*}$ ) species reported in the scientific collections of UFAM and Instituto Nacional de Pesquisas da Amazônia (INPA); $\left(^{* *}\right)$ occasional encounters.

\begin{tabular}{llll}
\hline \multirow{2}{*}{ Family/Species } & \multirow{2}{c}{ Survey } & \multicolumn{2}{c}{} \\
& & $2008 / 09 \quad 2015$ \\
\hline
\end{tabular}

LACERTOIDS

Amphisbaenidae

Amphisbaena alba (LINNAEUS, 1758)

Amphisbaena slevini SCHMIDT, 1936

Amphisbaena vanzolinii GANS, 1963

Dactyloidae

Dactyloa gr. punctata

Norops chrysolepis (DUMÉRI \& BIBRON, 1837)

Norops fuscoauratus (D'ORBIGNY, 1837 in

DUMÉRIL \& BIBRON, 1837)

Norops ortonii (COPE, 1868)

* $\quad * *$

\section{Gekkonidae}

Hemidactylus mabouia (MOREAU DE JONNĖS,

1818)

\section{Alopoglossidae}

Alopoglossus angulatus (LINNAEUS, 1758)

Alopoglossus atriventris DUELLMAN, 1973

$*$

*

Gymnophthalmidae

Bachia flavescens (BONNATERRE, 1789)

Leposoma sp.

Loxopholis sp. 
Table 1. Continued

\begin{tabular}{|c|c|c|c|}
\hline \multirow{2}{*}{ Family/Species } & \multirow{2}{*}{ Coll } & \multicolumn{2}{|c|}{ Survey } \\
\hline & & 2008/09 & 2015 \\
\hline Neusticurus bicarinatus (LINNAEUS, 1758) & & 1 & \\
\hline \multicolumn{4}{|l|}{ Iguanidae } \\
\hline Iguana iguana (LINNAEUS, 1758) & * & 2 & $* *$ \\
\hline \multicolumn{4}{|l|}{ Mabuyidae } \\
\hline Copeoglossum nigropunctatum (SPIX, 1825) & & 1 & \\
\hline \multicolumn{4}{|l|}{ Phyllodactylidae } \\
\hline Thecadactylus rapicauda (HOUTTUYN, 1782) & & ** & 1 \\
\hline \multicolumn{4}{|l|}{ Polychrotidae } \\
\hline Polychrus marmoratus (LINNAEUS, 1758) & * & & \\
\hline \multicolumn{4}{|l|}{ Sphaerodactylidae } \\
\hline Gonatodes humeralis (GUICHENOT, 1855) & & 34 & 34 \\
\hline \multicolumn{4}{|l|}{ Teiidae } \\
\hline Ameiva ameiva LINNAEUS, 1758 & & 6 & 2 \\
\hline Kentropyx calcarata SPIX, 1825 & & 17 & 5 \\
\hline Tupinambis teguixin (LINNAEUS, 1758) & & 2 & 2 \\
\hline \multicolumn{4}{|l|}{ Tropiduridae } \\
\hline Plica umbra umbra (LINNAEUS, 1758) & & 1 & 3 \\
\hline Uranoscodon superciliosus (LINNAEUS, 1758) & & 33 & 3 \\
\hline \multicolumn{4}{|l|}{ SNAKES } \\
\hline \multicolumn{4}{|l|}{ Aniliidae } \\
\hline Anilius scytale (LINNAEUS, 1758) & & & ** \\
\hline \multicolumn{4}{|l|}{ Boidae } \\
\hline Boa constrictor LINNAEUS, 1758 & * & & ** \\
\hline Corallus hortulanus (LINNAEUS, 1758) & * & & \\
\hline \multicolumn{4}{|l|}{ Colubridae } \\
\hline Chironius fuscus (LINNAEUS, 1758) & & ** & \\
\hline $\begin{array}{l}\text { Chironius multiventris SCHMIDT \& WALKER, } \\
1943\end{array}$ & * & & \\
\hline Drymoluber dichrous (PETERS, 1863) & & 2 & 1 \\
\hline Leptophis ahaetulla (LINNAEUS, 1758) & * & & \\
\hline Mastigodryas boddaerti (SENTZEN, 1796) & & ** & ** \\
\hline Oxybelis aeneus (WAGLER, 1824 in SPIX, 1824) & & ** & \\
\hline Oxybelis fulgidus (DAUDIN, 1803) & * & & \\
\hline Phrynonax polylepis (PETERS, 1867) & * & & \\
\hline Spilotes sulphureus (WAGLER in SPIX, 1824) & * & & \\
\hline \multicolumn{4}{|l|}{ Dipsadidae } \\
\hline Dipsas aff. catesbyi (SENTZEN, 1796) & * & & \\
\hline Erythrolamprus reginae (LINNAEUS, 1758) & & 1 & 2 \\
\hline Helicops angulatus LINNAEUS, 1758 & & 1 & \\
\hline Imantodes cenchoa LINNAEUS, 1758 & & & 1 \\
\hline Philodryas viridissima LINNAEUS, 1758 & & 1 & \\
\hline $\begin{array}{l}\text { Pseudoboa neuwiedii (DUMÉRIL, BIBRON \& } \\
\text { DUMÉRIL, 1854) }\end{array}$ & * & & \\
\hline
\end{tabular}

Table 1. Continued

\begin{tabular}{lccc}
\hline \multirow{2}{*}{ Family/Species } & \multirow{2}{*}{ Coll } & \multicolumn{2}{c}{ Survey } \\
\cline { 3 - 4 } & & $2008 / 09$ & 2015 \\
\hline Elapidae & & 1 & 1 \\
Micrurus lemniscatus (LINNAEUS, 1758) & $*$ & & \\
Micrurus spixii WAGLER in SPIX, 1824 & & & \\
Leptotyphlopidae & $*$ & & \\
Epictia tenella (KLAUBER, 1983) & & & \\
Viperidae & & 11 & 1 \\
\hline Bothrops atrox LINNAEUS, 1758 & & & \\
\hline
\end{tabular}

three species each. The most abundant species in the plots were Gonatodes humeralis (27.7\%), Uranoscodon superciliosus (14.7\%), Norops fuscoauratus (10.6\%) and Kentropyx calcarata (9.0\%). Three species were recorded in all plots: Gonatodes humeralis, Norops chrysolepis and Norops fuscoauratus.

\section{Effects of environmental parameters}

Species richness was positively related to edge distance $(\mathrm{p}=0.02)$ (Figure $2 \mathrm{a})$, marginally positively related to litter depth $(\mathrm{p}=0.05)$, and not related to stream size $(\mathrm{p}>0.05)$. The model explained $50 \%$ of observed variation (Richness = $-1.149+0.001$ log_stream size +0.007 edge distance +1.43 litter depth; Adjusted $\mathrm{R}^{2}=0.50 ; \mathrm{F}=4.08 ; \mathrm{P}=0.06$ ).

Species abundance was positively related to edge distance $(\mathrm{p}<0.01)$ (Figure $2 \mathrm{~b}$ ) and was not significantly related to litter depth and stream size $(p>0.05)$. The model explained $66 \%$ of observed variation (Abundance $=8.682+0.014$ stream size + 0.021 edge distance +0.43 litter depth; Adjusted $\mathrm{R}^{2}=0.66$; $\mathrm{F}=6.79 ; \mathrm{P}=0.02)$. While some species occupied the entire gradient from the center to the edge (e.g., Norops chrysolepis, N. fuscoauratus, Gonatodes humeralis, Dactyloa punctata), most of the species were not recorded near the edge of the forest fragment (Figure 3). Values per plot of squamate richness, total abundance and environmental variables are provided in Table 2.

\section{DISCUSSION}

Many squamate taxa that are widely distributed in the region of Manaus were absent or not detected in the UFAM fragment. Only 68.6\% of lacertoid species (Vitt et al. 2008) and $33.3 \%$ of snake species (Fraga et al. 2013b) recorded for the region were registered in the fragment. It is expected that relatively isolated urban fragments embedded in a matrix hostile to the movement of individuals would present a subset of the regional fauna, as extinction rates (stochastic or anthropogenic) are not compensated by colonization rates (Laurance et al. 2006a, b; Salomão et al. 2019). Most of the species recorded in the UFAM fragment were likely present since its isolation, given that low connectivity among forest fragments due to a hostile urban matrix decreases individual 

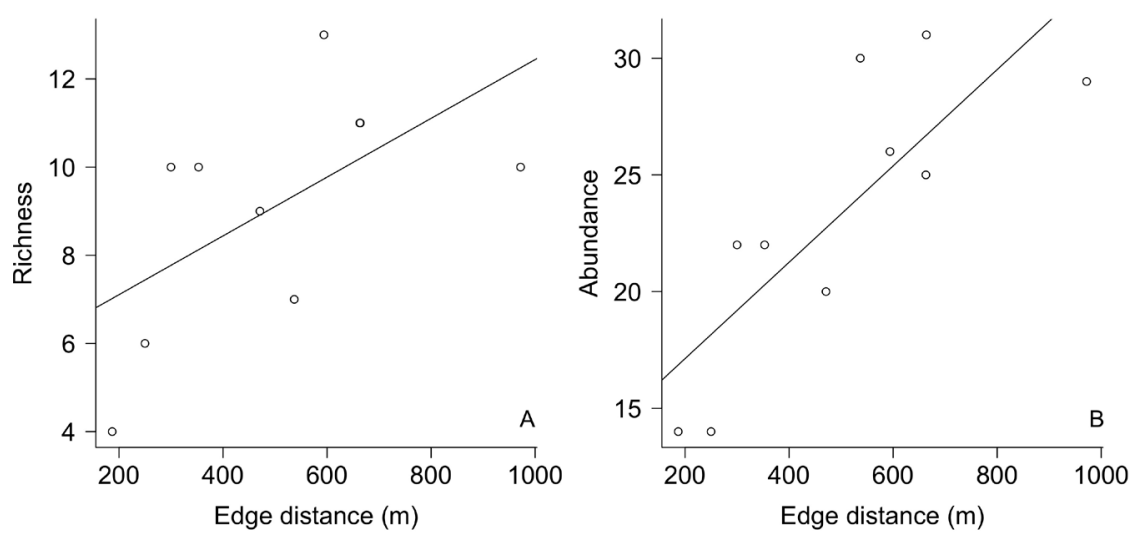

Figure 2. Squamate richness (A) and abundance (B) in relation to edge distance in 10 sampling plots in an urban forest fragment in Manaus, Brazilian Amazonia.

Table 2. Total squamate species richness, total individual abundance and average environmental parameters recorded for each of 10 riparian sampling plots at the UFAM forest fragment in Manaus, Brazilian Amazonia.

\begin{tabular}{ccccccc}
\hline Plot & Richness & Abundance & $\begin{array}{c}\text { Stream } \\
\text { width } \\
(\mathrm{m})\end{array}$ & $\begin{array}{c}\text { Stream } \\
\text { depth } \\
(\mathrm{m})\end{array}$ & $\begin{array}{c}\text { Leaf litter } \\
\text { depth } \\
(\mathrm{cm})\end{array}$ & $\begin{array}{c}\text { Edge } \\
\text { distance } \\
(\mathrm{m})\end{array}$ \\
\hline 1 & 13 & 26 & 2.38 & 0.23 & 5.33 & 594 \\
\hline 2 & 9 & 20 & 3.05 & 0.19 & 5.67 & 471 \\
\hline 3 & 10 & 22 & 6.15 & 0.19 & 4.33 & 353 \\
\hline 4 & 10 & 22 & 1.22 & 0.16 & 6.33 & 300 \\
\hline 5 & 10 & 29 & 1.41 & 0.15 & 3.87 & 972 \\
\hline 6 & 11 & 31 & 2.23 & 0.08 & 3.45 & 664 \\
\hline 7 & 4 & 14 & 3.40 & 0.08 & 3.38 & 187 \\
\hline 8 & 5 & 14 & 2.45 & 0.09 & 3.83 & 250 \\
\hline 9 & 11 & 25 & 6.60 & 0.04 & 4.00 & 663 \\
\hline 10 & 7 & 30 & 6.62 & 0.32 & 2.83 & 537 \\
\hline
\end{tabular}

and species exchange and restricts colonization (Laurance et al. 2011). Thus, the sampling of additional urban fragments in Manaus may reveal additional species from the regional pool. However, to understand how urban surroundings drive the decrease in species richness on a regional scale, studies encompassing matrix type effects should be conducted.

An alternative, but not exclusive, explanation for the observed low richness is the low detectability of squamate reptiles, mainly snakes, in forest environments (Fraga et al. 2014). However, our sampling effort by plot was similar to other recent ecological studies conducted in the region (Fraga et al. 2011; Fraga et al. 2014; Masseli et al. 2019). It is likely that a continued monitoring with the use of complementary sampling techniques, such as pitfall traps, will reveal additional species in the study area. Five lacertoid and two snake species were only observed in herpetological collections, indicating the importance of integrating complementary data to determine species composition of urban fragments.

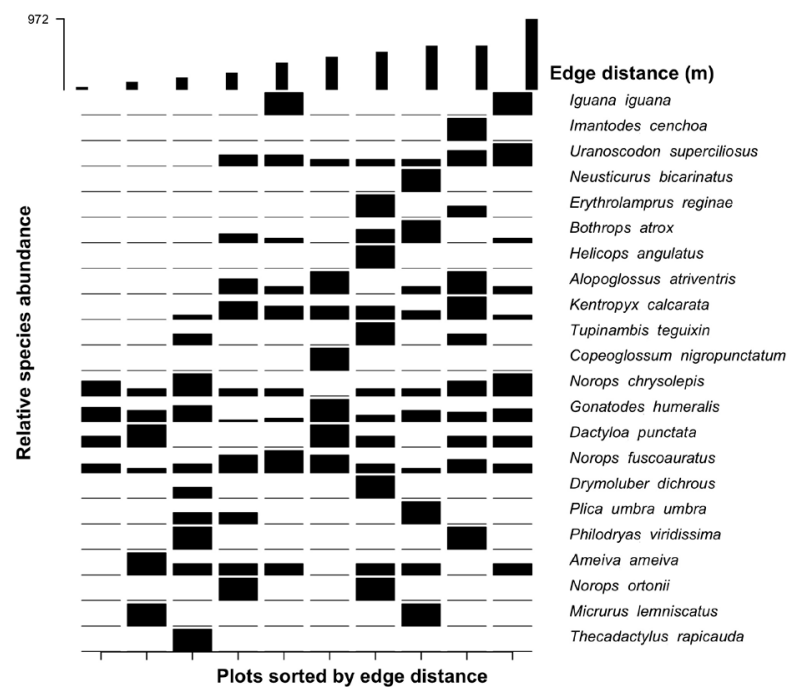

Figure 3. Occurrence and relative abundance of squamate species in relation to edge distance in 10 sampling plots in an urban forest fragment in Manaus, Brazilian Amazonia.

Our results indicated a positive relationship of squamate species richness and abundance of individuals with edge distance, as observed by Rojas and Pérez-Peña (2018) in Peru. Edge effect is known to influence various animal and plant taxa in tropical forests (Lewis et al. 2009; Laurance et al. 2011; Salomão et al. 2019). This influence possibly results from the interaction with environmental variables that vary concomitantly, such as temperature, luminosity and humidity (Laurance et al. 1997; 1998), which, in turn, affect habitat occupation by different species (Camargo and Kapos 1995; Quintela 1985; Laurance 2004). A study on amphibians in the same fragment also observed a positive relationship of edge distance with species richness (Tsuji-Nishikido and Menin 2011), although other studies on frogs from different forest fragments did not observe edge effect (Toral et al. 2002; Dixo and Martins 2008). These seemingly contradictory results are probably related to idiosyncratic factors such as geographic 
biases and limitations in sampling procedures (Gardner et al. 2007). Therefore, a study of a single fragment, as in our case, does not allow extrapolations regarding the effects of forest fragmentation, since all sampling points are conditioned by fragment size and degree of isolation.

Additionally, we observed a marginally significant and positive effect of litter depth on species richness. This effect has been reported in previous studies on herpetofauna (e.g. Vonesh 2001; Whitfield et al. 2007; Folt and Reider 2013;) and could be related to an increase of prey and refuge availability both for lizards and snakes (Vitt et al. 2008; Fraga et al. 2013a; Faria et al. 2019). Stream size was not related to either abundance or richness of squamates, as observed for frogs in the same study area (Tsuji-Nishikido and Menin 2011), indicating that lizard and snake assemblages are not strongly related to structural characteristics of these water bodies. Previous studies in central Amazonia have also shown that squamate assemblages are not affected by stream features, but mainly by the distance gradient in relation to streams (Fraga et al. 2011; Faria et al. 2019).

\section{CONCLUSIONS}

Our study indicated that the central Amazonian UFAM forest fragment contains a squamate assemblage that consists of a subset of the regional species pool and is impaired by the edge effect, with a decrease of species richness and abundance of individuals from the center to the borders. Our findings call for future research in forest fragments of different sizes, degrees of isolation and types of urban matrix, aiming to elucidate the role of cities in the conservation of the Amazonian fauna.

\section{ACKNOWLEDGMENTS}

We thank Claudia Keller, Paulo Bobrowiec, and anonymous reviewers for insightful suggestions on this manuscript; Maria Ermelinda Oliveira for continuous support during the field surveys; the curators of Universidade Federal do Amazonas (UFAM) and Instituto Nacional de Pesquisas da Amazônia (INPA) for providing access to the herpetological collections. We also thank Ministério da Ciência, Tecnologia e Inovaçẫo (MCTI), Conselho Nacional de Desenvolvimento Científico e Tecnológico (CNPq) and Pró-Reitoria de Pesquisa e Pós-Graduação (PROPESP) of UFAM for financial support (\# 470375/2006-0, 555268/2006-3, 457545/2012-7. 461573/2014-8, PIB-B/0158/2018). Campus UFAM is part of the Programa de Pesquisa em Biodiversidade (PPBio) of MCTI. This study was supported by fellowships from CNPq to TAC, LF and DMC, and research productivity grants to MM and ILK.

\section{REFERENCES}

Alvares, C.A.; Stape, J.L.; Sentelhas, P.C.; De Moraes, G.; Leonardo, J.; Sparovek, G. 2013. Köppen's climate classification map for Brazil. Meteorologische Zeitschrift, 22: 711-728.

Araújo, M.B.; Pearson, R.G. 2005. Equilibrium of species' distribution with climate. Ecography, 28: 693-695.

Avila-Pires, T.C.S. 1995. Lizards of brazilian Amazonia (Reptilia: Squamata). Zoologische Verhandelingen, 299: 1-706.

Camargo, J.L.C.; Kapos, V. 1995. Complex edge effects on soil moisture and microclimate in central Amazonian forest. Journal of Tropical Ecology, 11: 205-211.

Chace, J.F.; Walsh, J.J. 2006. Urban effects on native avifauna: a review. Landscape and urban planning, 74: 46-69.

Costa, H.C.; Bérnils, R.S. 2018. Répteis do Brasil e suas unidades federativas: lista de espécies. Herpetologia Brasileira, 7: 11-57.

Crump, M.L.; Scott Jr, N.J. 1994. Visual encounter surveys. In: Heyer, W.R.; Donnely, M.A.; McDiarmid, R.W; Hayek, L.C.; Foster, M.S. (Ed.). Measuring and Monitoring Biological Diversity: Standard Methods for Amphibians. Smithsonian Institute Press, Washington, DC, p.84-92.

Dixo, M.; Martins, M. 2008. Are leaf-litter frogs and lizards affected by edge effects due to forest fragmentation in Brazilian Atlantic forest? Journal of Tropical Ecology, 24: 551-554.

Faria, A.S.; Menin, M.; Kaefer, I.L. 2019. Riparian zone as a main determinant of the structure of lizard assemblages in upland Amazonian forests. Austral Ecology, 44: 850-858.

Folt, B.; Reider, K.E. 2013. Leaf-litter herpetofaunal richness, abundance, and community assembly in mono-dominant plantations and primary forest of northeastern Costa Rica. Biodiversity and Conservation, 22: 2057-2070.

Fraga, R.; Lima, A.P.; Magnusson, W.E. 2011. Mesoscale spatial ecology in a tropical snake assemblage: the width of riparian corridors in central Amazon. Herpetological Journal, 21: 51-57.

Fraga, R.; Lima, A.P.; Prudente, A.L.C.; Magnusson, W.E. 2013b. Guia de Cobras da Regiāo de Manaus, Amazônia Central. Editora Inpa, Manaus, 303p.

Fraga, R.; Magnusson, W.E.; Abrahão, C.R.; Sanaiotti, T.; Lima, A.P. 2013a. Habitat selection by Bothrops atrox (Serpentes: Viperidae) in Central Amazonia, Brazil. Copeia, 2013: 684-690.

Fraga, R.; Stow, A.J.; Magnusson; W.E.; Lima, A.P. 2014. The costs of evaluating species densities and composition of snakes to assess development impacts in Amazonia. PloS ONE, 9: e105453.

Gardner, T.A.; Barlow, J.; Peres, C.A. 2007. Paradox, presumption and pitfalls in conservation biology: the importance of habitat change for amphibians and reptiles. Biological Conservation, 138: 166-179.

Grimm, N.B.; Grove, J.G.; Pickett, S.T.; Redman, C.L. 2000. Integrated approaches to long-term studies of urban ecological systems: Urban ecological systems present multiple challenges to ecologists-Pervasive human impact and extreme heterogeneity of cities, and the need to integrate social and ecological approaches, concepts, and theory. AIBS Bulletin, 50: 571-584.

IBGE. 1970. Instituto Brasileiro de Geografia e Estatística. Sinopse do censo demográfico 2010 Brasil. (https://censo2010.ibge. gov.br/sinopse/index.php?dados=6). Accessed on 24 Oct 2018. 
IBGE. 2018. Instituto Brasileiro de Geografia e Estatística. Manaus: Panorama. (https://cidades.ibge.gov.br/brasil/am/manaus/ panorama). Accessed on 24 Oct 2018.

Laurance, W.F. 2002. Hyperdynamism in fragmented habitats. Journal of Vegetation Science, 13: 595-602.

Laurance, W.F. 2004. Forest-climate interactions in fragmented tropical landscapes. Philosophical Transactions of the Royal Society B, 359: 345-352.

Laurance, W.F.; Camargo, J.L.; Luizão, R.C.; Laurance, S.G.; Pimm, S.L.; Bruna, E.M.; et al. 2011. The fate of Amazonian forest fragments: a 32-year investigation. Biological Conservation, 144: 56-67.

Laurance, W.F.; Ferreira, L.V.; Rankin-de Merona, J.M.; Laurance, S.G. 1998. Rain forest fragmentation and the dynamics of Amazonian tree communities. Ecology, 79: 2032-2040.

Laurance, W.F.; Laurance, S.G.; Ferreira, L.V.; Rankin-de Merona, J.; Gascon, C.; Lovejoy, T.E. 1997. Biomass collapse in Amazonian forest fragments. Science, 278: 1117-1118.

Laurance, W.F.; Nascimento, H.; Laurance, S.G.; Andrade, A.; Fearnside, P.M.; Ribeiro, J. 2006a. Rain forest fragmentation and the proliferation of successional trees. Ecology, 87: 469-482.

Laurance, W.F.; Nascimento, H.; Laurance, S.G.; Andrade, A.; Ribeiro, J.; Giraldo, J.P.; Lovejoy, T.E.; Condit, R.; Chave, J.; D’Angelo, S. 2006b. Rapid decay of tree community composition in Amazonian forest fragments. Proceedings of the National Academy of Sciences of the United States of America, 103: 19010-19014.

Laurance, W.F.; Vasconcelos, H.L. 2009. Consequências ecológicas da fragmentação florestal na Amazônia. Oecologia Brasiliensis, 13: 434-451.

Lewis, S.L.; Lloyd, J.; Sitch, S.; Mitchard, E.; Laurance, W.F. 2009. Changing ecology of tropical forests: evidence and drivers. Annual Review of Ecology, Evolution, and Systematics, 40: 539-549.

Magnusson, W.E.; Lima, A.P.; Luizão, R.; Costa, F.R.; Castilho, C.V.; Kinupp, V.F. 2005. RAPELD: A modification of the gentry method for biodiversity surveys in long-term ecological research sites. Biota Neotropica, 5: 1-6.

Marcon, J.L.; Cruz, J.; Menin, M.; Carolino, O.T.; Gordo, M. 2012. Biodiversidade fragmentada na floresta do campus da Universidade Federal do Amazonas: conhecimento atual e desafios para a conservação. In: Marcon, J.L.; Menin, M.; Araújo, M.G.P.; Hrbek, T. (Eds.). Biodiversidade Amazônica: Caracterização, Ecologia e Conservação. Edua, Manaus, p.221278.

Martins, M.; Oliveira, E.M. 1998. Natural history of snakes in forests of the Manaus region, Central Amazonia, Brazil. Herpetological Natural History, 6: 78-150.

Masseli, G.S.; Bruce, A.D.; Santos, J.G.; Vincent, T.; Kaefer, I.L. 2019. Composition and ecology of a snake assemblage in an upland forest from Central Amazonia. Anais da Academia Brasileira de Ciências, 91: e20190080.

Neckel-Oliveira, S.; Gordo, M. 2004. Anfíbios, Lagartos e Serpentes do Parque Nacional do Jaú. In: Borges, S.H.;
Iwanaga, S.; Durigan, C.C.; Pinheiro, M.R. (Eds.). Janelas para a Biodiversidade no Parque Nacional do Jaú: Uma Estratégia para o Estudo na Biodiversidade da Amazônia. Fundação Vitória Amazônica, Manaus, p.161-173.

Nery, L.C.; Lorosa, E.S.; Franco, A.M. 2004. Feeding preference of the sand flies Lutzomyia umbratilis and L. spathotrichia (Diptera: Psychodidae, Phlebotominae) in an urban forest patch in the city of Manaus, Amazonas, Brazil. 2004. Memórias do Instituto Oswaldo Cruz, 99: 571-574.

Peixoto, G.M.; Fraga, R.; Araújo, M.C.; Kaefer, I.L.; Lima, A.P. 2020. Hierarchical effects of historical and environmental factors on lizard assemblages in the upper Madeira River, Brazilian Amazonia. PLoS ONE 15: e0233881.

Pinto, M.G.M. 2006. Diversidade beta, métodos de amostragem e influências de fatores ambientais sobre uma comunidade de lagartos na Amazônia Central. Doctoral thesis, Instituto Nacional de Pesquisas da Amazônia/Fundação Universidade do Amazonas, Brasil. 91p.

Quintela, C.E. 1985. Forest fragmentation and differential use of natural and manmade edges by understory birds in central Amazonia. M.Sc. thesis, University of Illinois, USA. 65p.

R Core Team. 2019. R: A language and environment for statistical computing. R Foundation for Statistical Computing, Vienna, Austria. (https://www.Rproject.org/).

Rojas, R.R.; Pérez-Peña, P.E. 2018. Evidencia preliminar del efecto borde en anfibios de la Reserva Nacional Pucacuro, al norte de la Amazonía peruana. Revista del Instituto de Investigaciones de la Amazonía Peruana, 27: 55-67.

Salomão, R.P.; Alvarado, F.; Baena-Díaz, F.; Favila, M.E.; Iannuzzi, L.; Liberal, C.N.; Santos, B.A.; Vaz-de-Mello, F.Z.; GonzálezTokman, D. 2019. Urbanization effects on dung beetle assemblages in a tropical city. Ecological Indicators, 103: 665-675.

Toral, C.; Feinsinger, P.; Crump, M.L. 2002. Frogs and a cloud-forest edge in Ecuador. Conservation Biology, 16: 735-744.

Tsuji-Nishikido, B.M.; Menin, M. 2011. Distribution of frogs in riparian areas of an urban fragment in Central Amazonia. Biota Neotropica, 11: 63-70.

Vitt, L.; Magnusson, W.E.; Avila-Pires, T.C.; Lima, A.P. 2008. Guia de Lagartos da Reserva Adolpho Ducke-Amazônia Central. Áttema Design Editorial, Manaus. 176p.

Vonesh, J.R. 2001. Patterns of richness and abundance in a tropical African leaf-litter herpetofauna. Biotropica, 33: 502-510.

Whitfield, S.M.; Bell, K.E.; Philippi, T.; Sasa, M.; Bolaños, F.; Chaves, G.; Savage, J.M.; Donnelly, M.A. 2007. Amphibian and reptile declines over 35 years at La Selva, Costa Rica. Proceedings of the National Academy of Sciences, 104: 8352-8356.

Zimmerman, B.L.; Rodrigues, M.T. 1990. Frogs, snakes, and lizards of the INPA - WWF reserves near Manaus, Brazil. In: Gentry, A.H. (Ed.). Four Neotropical Rainforests. Yale University Press, New Haven, p.426-454.

\author{
RECEIVED: 29/11/2019 \\ ACCEPTED: $18 / 06 / 2020$ \\ ASSOCIATE EDITOR: Paulo E. Bobrowiec
}

